\title{
The Use of Revision Version of Archiving Interactive Digital Book Based on the Curriculum 2013 in Vocational School
}

\author{
Patni Ninghardjanti*, C. Dyah Sulistyaningrum Indrawati, Andre N. Rahmanto, \\ Chairul Huda Atma Dirgatama \\ Department Education of Office Administration, Sebelas Maret University, Indonesia
}

\begin{tabular}{l}
\hline \hline Article Info \\
\hline Article history: \\
Received Sept 15, 2017 \\
Revised Dec 07, 2017 \\
Accepted Jan 08, 2018 \\
\hline
\end{tabular}

Keywords:

Curricullum 2013

Digital book

Use pattern

\begin{abstract}
Information and communication technology has a large potency to help teachers and students to in a successful learning. The implementation of revision version of curriculum 2013 based digital book in school should include need analysis, preparing the necessary need, designing learning model and its development. The use of revision version of the curriculum 2013 based digital book is a decision made by teachers based on learning design. Considering a survey conducted, it can be found that there has bee no archiving book corresponding to the revision version of 2013 curriculum. The use of revision version of curriculum 2013 based digital book is expected to improve the students' learning interest and to optimize the teachers' role as learning designer and mediator.
\end{abstract}

Copyright () 2018 Institute of Advanced Engineering and Science. All rights reserved.

\section{Corresponding Author:}

Patni Ninghardjanti,

Department Education of Office Administration,

Sebelas Maret University,

Jalan Ir. Sutami 36 A, 57126, Surakarta, Indonesia

Email: buning@fkip.uns.ac.id

\section{INTRODUCTION}

Digitalization era results in big change from tradition to modern. The change occurring encourages the teachers to improve their quality through mastering Information and Communication Technology (ICT). Information and Communication Technology has a large potency to help teachers and students in achieve a successful learning. The learning occurring in Business and Management field of Vocational School still uses teaching material limited to learning material concept mastery thereby impact on the output of graduates unready to enter into business and industrial world and less maximal practical value obtained.

Teaching material is an important part of education implementation in school, as through teaching material the teachers can implement learning more easily and the students will be more helpful and will learn more easily. Teaching material can be prepared in varying forms according to need and characteristics of teaching material to be presented [1]. Government Regulation Number 19 of 2005 [2] about Standard National Education mentions that book is a part of education service and government obligatorily provides textbook for all subjects at school. National Education Department (Depdiknas) has run Digital Book program or called Buku Sekolah Elektronik (BSE=Electronic School Book. The problem arising in the field is that nearly all schools have not been able to realize the program due to: 1) less preparation of socialization, 2) limited supporting infrastructure, 3) less interactive BSE version of digital book, 4) BSE version of teaching book not equipped with practical sheet and practical instruction, and 5) BSE version of digital book less consistent with revision version of Curriculum 2013 Syllabus. Actually government's program is very good and useful to education, particularly in Vocational School. In addition, information can be acquired about teachers' wish for interactive digital book thereby can consider such technical matters as including concept map, alternative learning model used, increasing practical aspect, and material writing procedure. 
Several matters related to components of content feasibility, presentation and language will be synchronized with revision version of 2013 curriculum oriented to business world and industrial world so that it expected that interactive digital book developed can support the active learning.

Teacher as a professional is expected to have competency of using teaching material in the form of interactive digital. Interactive digital book is expected to facilitate the students to learn independently, so that the students can learn according to their own ability and can fulfill the competency to be mastered by the students [3]-[5]. It refers to governments' program related to policy and programming to meet the students' right to get and to use digital media facility, thereby can provide information and support to the students in learning process [6]-[7].

Interactive digital book based on curriculum 2013 is expected to help learning activity operated using computer, laptop, and smartphone. The learning existing in the class becomes interactive, active and joyful through ready-to-use interactive components such quiz, puzzle, interactive simulation and other various attractive components thereby attracting the students' attention and interest in the learning process both inside or outside school.

\section{RESEARCH METHOD}

This research employed a survey research design. The method used was descriptive one. This research was taken place in Office Administration Specialty of Vocational Middle Schools throughout Surakarta Ex-Residency areas. Techniques of collecting data used were: in-depth interview with informant related to Office Administration teaching material; passive observation on learning activity; and document analysis used to analyze the teaching material documents and other supporting documents. Meanwhile, the technique of collecting data used was tried out using survey questionnaire distributed to teachers and students. Considering this, the qualitative data was analyzed using an interactive analysis [8].

\section{RESULTS AND ANALYSIS}

The result of research included: 1) teachers' knowledge on digital book, 2) teachers' willingness to utilize digital book, 3) the use of digital book by teacher in vocational school, and 4) the use of digital book as primary teaching material.

The result of percentage shows that teachers' knowledge on digital book as follows, about $83 \%$ of teachers has known and utilized digital book, $10 \%$ teachers have known and had utilized digital book, and $7 \%$ of teachers have not known yet and had not utilized digital book. Concise description of this result can be seen in figure 1.
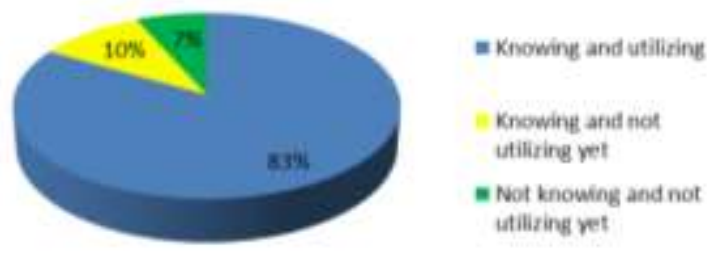

Figure 1. Teachers' knowledge on digital book

Teachers' willingness to utilize digital book is as follows: $83 \%$ of teachers have known and utilized digital book, $10 \%$ willing to use it as teaching material. It can be described briefly in figure 2 .

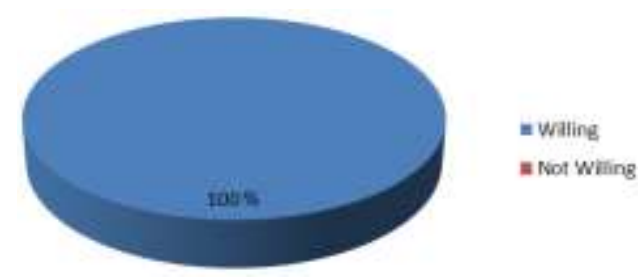

Figure 2. Teachers' willingness to utilize digital book 
The utilization of digital book by teachers in vocational school is as follows: $73 \%$ of teachers have utilized digital book as primary teaching material, $13 \%$ have utilized digital book as task structure material, $7 \%$ have utilized digital book as independent duty material, 3\% have utilized digital book as enrichment material. It can be described briefly in figure 3 .
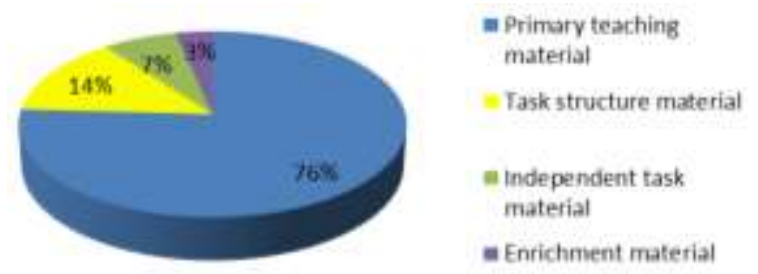

Figure 3. The utilization of digital book by teacher in vocational school

The utilization of digital book as primary teaching material is as follows: $80 \%$ of teachers always utilize digital book as primary teaching material, $13 \%$ often utilized digital book as primary teaching material, 7\% rarely utilized digital book as primary teaching material. It can be described briefly in figure 4 .

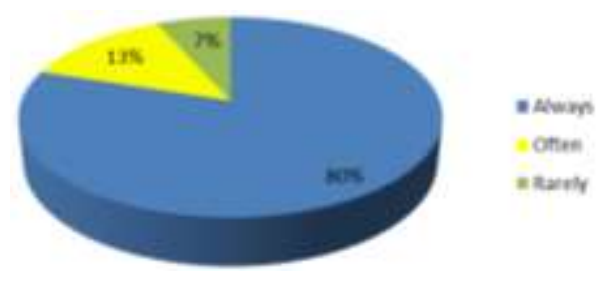

Figure 4. The utilization of digital book as primary teaching material

Considering the result of research conducted, teachers have knowledge on digital book or have known and utilized it well, 2) teachers' willingness in utilizing digital book is very high, 3) the utilization of digital book by teachers in Vocational Middle School is very high in using primary teaching material, and 4) the utilization of digital book as primary teaching material highly supports learning inside and outside class. Meanwhile, Ardiyanta's [9] study conducted in Vocational Middle Schools throughout Sidoarjo found that there are some constraints the teachers experienced in utilizing BSE as digital book at school. Considering the data of research, it can be seen that $47 \%$ of teachers answer that the constraint is limited number of BSE. Meanwhile, data of Depdiknas shows that there are more than 407 BSEs currently for all education levels. Those numbers will increases continuously over years [10]. Effectiveness is the ability having appropriate objective in achieving the objective wished and effectiveness as the expedience obtained after learning activity [11].

The revision version of Archiving Digital Book based on the curriculum 2013 utilized has EPUB extension so that it is expected to facilitate and to be used flexible as it can be used on computer set, PC, laptop, smartphone, and gadget so that it becomes more portable, can be used anywhere, anytime and by anyone. It makes digital book is acceptable to students and teachers. It is in line with Roesnita \& Zainab A.N's study [12] in a journal entitled The Pattern of E-Book Use Amongst Undergraduates In Malaysia: A Case of to Know is to Use finding that digital book is usable and is used particularly in task writing and project work. It can indirectly improve the effectiveness of learning.

\section{CONCLUSION}

Information and Communication technology has large potency to help teachers and students achieve successful learning. The implementation of digital book based on revision version of curriculum 2013 in school should include need analysis, preparing the necessary need, designing learning model and its development. The use of revision version of the curriculum 2013 based digital book is a decision made by teachers based on learning design. The archiving digital book based on revision version of curriculum 2013 
utilized has EPUB extension so that it is expected to facilitate and to be used flexibly as it can be used on computer set, pc, laptop, smartphone, and gadget so that it is portable, can be used anytime, anywhere and by anyone. It makes digital book acceptable to students and teachers.

\section{ACKNOWLEDGEMENTS}

Thank to Subject Teacher Discussion (MGMP) of Office Administration teachers throughout Surakarta Ex-Residency.

\section{REFERENCES}

[1] Depdiknas. Pengembangan Model Pembelajaran Tatap Muka Penugasan Terstruktur dan Tugas Mandiri Tidak Terstruktur. Jakarta. Direktorat Pembinaan Sekolah Menengah Atas, Dikdasmen, 2008.

[2] Pemerintah Nomor 19 Tahun 2005. Standar Nasional Pendidikan. Kedaulatan Rakyat, Edisi 5 Maret 2009.

[3] Liaw \& Huang. "Investigating Learner Attitudes Toward E-Books as Learning Tools: Based on The Activity Theory Approach”. Journal Interactive Learning Environments. ISSN: 1049-4820, 2014.

[4] Chen, H. Y. "Exploring The Reasons For Using Electric Books And Technologic Pedagogical And Content Knowledge Of Taiwanese Elementary Mathematics And Science Teachers". Journal TOJET: Educational Technology, Vol. 12, No. 2, pp. 131-141, 2013.

[5] Bradshaw. "Multimedia Textbooks and Student Learning". MERLOT Journal of Online Learning and Teaching, Vol 1, No.2, pp. 1-9, 2005.

[6] Andrea, Jenny, Joanna \& Amelia. "Using E-Books to Create Shared Learning Experiences Between Students of Differing Abilities". Journal of Occupational Therapy, Schools, \& Early Intervention. Vol.9, No.1, pp. 12-18, 2016.

[7] Letchumanan, Malathi \& Tarmizi, R. A. "Utilization Of E-Book Among University Mathematics Students". Journal Elsevier: Social and Behavioral Sciences. Vol. 8, No.1, pp. 580-587. 2010.

[8] Miles, M.B. dan Huberman, A.M. Analisis Data Kualitatif: Buku Sumber Tentang Metode-Metode Baru. UI Press. Jakarta, 1992.

[9] Ardiyanta. "Pemanfaatan Buku Sekolah Elektronik Sebagai Bahan Ajar Guru Program Produktif Sekolah Menengah Kejuruan". Jurnal Teknologi dan Kejuruan, Vol. 35, No. 2, pp. 163-172, 2012.

[10] Indah. Manfaat BSE. (online), (http://www.episodeqita.blogspot.com/2010/12/manfaat-BSE.html, diakses 23 Mei 2017), 2010.

[11] Dirgatama. "The Effectiveness Of Archieved E-Book Based Curriculum 2013 As An Effort To Improving Learning Outcomes In Vocational School”. Journal of Education and Learning. Vol.11, No. 3, pp. 405-410, 2017.

[12] Roesnita \& Zainab A.N. "The Pattern of E-Book Use Amongst Undergraduates In Malaysia: A Case of to Know is to Use". Malaysian Journal of Library \& Information Science. Vol 10, No. 2, pp. 1-23, 2005 


\section{BIOGRAPHIES OF AUTHORS}

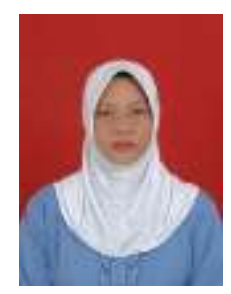

Dra. Patni Ninghardjanti, M.Pd, was born in Surakarta on 06 April 1963. The last edition of Education Research and Evaluation Education UNY, a journal that has been published in aspapi journal, is also active in book writing: Computer administration practice, Office Administration Computer. He is currently a lecturer in the FKIP UNS office administration education program and is active in ASPAPI.

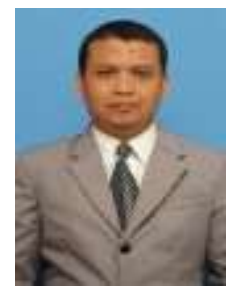

Dr. Andre N. Rahmanto, S.Sos., M.Si was born in Bojonegoro on July 15, 1977. The last education of S3 Communication Science UNPAD, the journal was published in Mass Communication Journal, Activita Community Empowerment Journal, and vocational education journal. Also active in book writing: Cooperate with Colleagues and Customers, Office Administration: Material Public Relations, Introduction Public Relations, Administration, and Public Relations \& Keprotokolan.Currently a lecturer in the study program of FKIP UNS office administration and as Head of Public Relations UNS, ASPAPI.

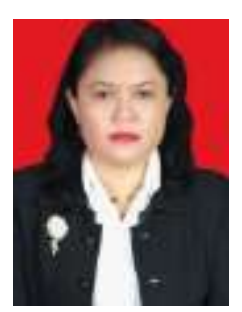

Dr. C. Dyah Sulistyaningrum Indrawati, MPd was born in Karanganyar dated November 22, 1961. The last education S3 Science Education UNS. journal papers were published in HISPISI Journals, Dewantara, ICTTE, AGBA international proceedings, vocational education journals, and INFORMATION An International Interdisciplinary Journal and Journal of Edulearn. Also active in book writing: Secretarial, English steno, ethics and personality, incoming and outgoing mail, education module, mail handling.He is currently a lecturer in the FKIP UNS office administration education program and is active in ASPAPI.

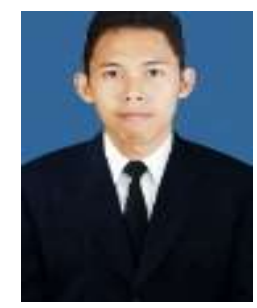

Chairul Huda Atma Dirgatama, S.Pd, M.Pd was born in Kebumen on December 19, 1992. The last education of S2 Economic Education. Journal work was published in Jurnal JIKAP, Journal of Edulearn. Also active in the writing of books: digital archives, public relations. He is currently a lecturer in the FKIP UNS office administration education program and is active in ASPAPI. 